\title{
Revitalization of Farming Rituals as Part of Language Maintenance of Balinese Registers: A Language and Cultural Studies
}

\author{
Ni Wayan Sartini ${ }^{1}$, Ketut Artawa ${ }^{2}$, Nyoman Sukiada ${ }^{3}$ \\ \{1ni-wayan-s@fib.unair.ac.id, ${ }^{2}$ ketut_artawa@unud.ac.id,nyomansukiada@yahoo.com\} \\ ${ }^{1}$ Universitas Airlangga, ${ }^{2,3}$ Universitas Udayana
}

\begin{abstract}
A functional shift on the use of farming area nowadays has affected the farming culture in Bali. Due to globalization, some traditions regarding the farming are rarely performed. The traditions include rituals that farmers do for certain purposes. This study aims to (1) preserve the farming tradition and culture; (2) preserve particular Balinese registers relating to the farming rituals. The data were collected in the second subak (a terraced farming area), Pasedehan Yeh Lauh, Peguyangan Kangin Village, South Denpasar SubDistrict. The data collections were undergone through observations, interviews, and some literatures. From the data, it has been found that many Balinese registers regarding the farming rituals are no longer used. This happens due to the lack of farming areas and the globalization impact in which practicality is prioritized. In the farming rituals, some registers that are not popular include kober, 'flag', ngeed 'a flag made of bamboo', jangu 'one kind of tubers', kakul 'snail' ngingu'serve', etc. Apparently, Balinese registers can be preserved by the revitalization of farming rituals, so that they are not extinct due to the modernization.
\end{abstract}

Keywords: Balinese registers, Balinese society, revitalization of farming rituals, language maintenance

\section{Introduction}

Modernization spreading to all aspects of Balinese society's life has led to the change of tourism industry in Bali. One impact of the modernization can be seen in the sector of farming that is one of the assets and cultural capitals to preserve a tradition. The lack or the loss of farming areas may indicate that Bali will lose farming ritual traditions considered as a cultural heritage having a local wisdom. In fact, the local wisdom has a high cultural value called adi luhung for Balinese society. The value gives rules to Balinese about how to keep the balance between nature and its environment especially the farming environment. In the present context, culture and local tradition are assumed as out of date; consequently, the development plans do not involve local society particularly the elders who understand their environment and nature. To maintain the local traditions from being extinct, some efforts and strategies are needed. One of the traditions that can be maintained is rituals. Ritual is a permanent routine or 
behavior which does not contain any influential intention apart from being communication and symbolization and is related to magical power [1]. Ritual is a collective act which generally focuses on the participants in various places and generates the sense of shared identity and feelings which can be maintained with the proper symbols [2]. Even if ritual communication has meaningful message for the community that believes in it by heart, it is often considered as irrational and hard to understand by the people outside the community [3]. Conducting rituals in the modern age might be considered archaic, yet people need to discover their meanings and purposes in order to use them properly [4].

Rituals are divided into four, that is magic action, religious action, substantive or constitutive ritual, and factitive ritual [5]. The farming ritual in Bali, especially with the usage of subak, belongs to religious action which distinguish the subak system with other local irrigation systems that are commonly executed in other regions in Indonesia [6]. According to Ref. [7], two essential things that become the concern in the religious action are (a) the ceremonies in a nation's culture which usually becomes the cultural element that appears explicitly, and (b) the ethnographic material regarding religious ceremony is required to arrange the theories of the origin of religion. In this case, the farming ritual does not only function to administer the climate, but it also functions to concentrate the relationships among the farmers as well as their interdependencies [8]. Particularly for Balinese farmer, the use of rituals and mantras in their farming activities is more crucial than chemicals and pesticides, especially in preventing pests and diseases [9]. The farming ritual is also believed to protect the rice crop and ensure the good harvest [10]. The present study aimed to maintain Balinese registers used in the farming ritual traditions by Balinese society. Maintaining Balinese registers relating to the farming ritual traditions is very important, so that the next generations of Balinese society will not lose their identity as agrarian society since they are west oriented. In fact, the local traditions have some cultural values which can be adapted in the globalization context and be in line with the Indonesians' cultural context. The revitalization of the farming ritual traditions can be one of the ways in language maintenance i.e. Balinese maintenance. Generally, the maintenance of registers relating to the farming rituals can preserve the Balinese language. This means preserving language means preserving culture. Language and culture have a close relationship, use of language means practising a culture [11][12]. In semiotic perspective, the revivalization, revitalization, and reinterpretation of local wisdoms need such particular ways of thinking as synthesizing, and creatively and newly defining the local wisdom as an ideal and contextual text [13]. In the perspective of Ref. [14] $\&$ [15], Balinese society cannot only be trapped in the existing connotation meaning, but they also have to find a new connotation meaning through the revitalization; as a result, a more contextual interpretation can be formed. The revitalization of farming rituals means how the tradition can give a new interpretation to the new local wisdom specifically to the ecological local wisdom in the farming sector. The revitalization means having a reborn of the dead local wisdom, giving a spirit and a new soul to the local wisdom; the reinterpretation means giving a new interpretation to the local wisdom. The revitalization of the farming rituals gives some positive impacts on language maintenance and farming culture that nowadays becomes less and less to be practiced due to the development and tourism industry.

There are several studies focusing on the registers of farming rituals. Ref. [16] attempted to investigate the relationship of registers used in Japanan village, Klaten, with the farming activities in the village. They discovered various lingual units that formed the registers related to the farming activities in Japanan village. Then, Ref. [17] sought the registers used by the farmers of Boja village, Kendal, in planting rice and the cultural meaning contained in the registers. They found out that the registers used by the farmers of Boja village contained the 
cultural meanings which highlighted the exemplary natures that should be possessed by humankind as leaders. Another study conducted by Ref. [18] focused on the registers in Neduhin ritual in Bunutin village, Bangli, as well as the functions and meanings of the ritual. They explored that Neduhin ritual had manifest and latent functions and it owned the religious, educational, and prosperous meanings. By observing the previous studies, the present study is a cultural linguistic study or ethnolinguistics which concerns the language or registers used in religious rituals on farming by Balinese society as the research gap. The language used in social cultural context and the role of language in the culture development and preservation along with the social structure are the main concerns. In this case, in anthropology linguistics, the language will be closely observed through a fundamental anthropology concept and a culture; besides, the interpretation of language use and language forms, registers, and language style will be identified [19][20].

\section{Research Method}

This research is a qualitative research which aims at profoundly explaining a phenomenon through the in-depth data collection and emphasizing the data profundity. The research location was the Subak Kedua of Pasedahan Yeh Lauh, Peguyangan Kangin village, West Denpasar sub-district. The data was obtained with the observation, interview, and document study methods supported by the recording and note-taking techniques. For the interview, the informants were determined by the certain criteria which were suitable for the goals to be achieved. The interview was conducted to the key informants who acquired reflective ability, took the time for the interview, were passionate, and owned the extensive knowledge regarding the studied issue, that is the elder people in the custom as well as the cultural and religious experts with a Hindu background. The obtained data of observation, interview, and document study results was then classified, analyzed, and critiqued related with the cultural assumption and meaning as well as flexibility, reflectivity, and objectivity.

\section{Results And Discussion}

There are two farming rituals; farming rituals on rice fields (pesawahan) and plantation rituals [21]. The farming rituals on rice fields include (a) ritual of planting the rice, and ritual of pest repellent (nangluk mrana). The rituals performed by the Balinese society in Subak Kedua, Pasedehan Yeh Lauh, Peguyangan Kangin Village, South Denpasar Sub-District according to awig-awig (rules) in performing the rituals in subak are:

\subsection{Ritual of Ngendagin 'starting the activity in a rice field'}

Ritual of ngendagin means starting an activity in the rice field. Ngendagin is derived from endag 'rise', 'start'. It aims to ask the blessing of Sang Hyang Ibu Pertiwi as the Goddess of Earth and the Goddess of Uma as the ruler of rice field. In this ritual, ngendagin, endag, pengalapan, geti-geti, bunga sulasih are used as registers.

\subsection{Ritual of Mapag Toya / Mendak Toya 'fetching the water'}

This ritual aims to fetch the water. Mapag means 'fetch' and toya means 'water'. It is performed by a group of farmers to ask the God of Vishnu as the representation of God to give 
them rain because the farmers start doing their rice field. The registers that are maintained include mapag, toya, and other offering media.

\subsection{Ritual of Ngurit 'spreading the seed'}

Ngurit is derived from urit 'seedling' and ngurit means 'doing the seedling' [21]. Ngurit means a farming activity i.e. spreading the seed that follows some rules in subak such as presenting an offering to Ida Bhatari Gangga in a lake. It aims to ask the God's blessing, so that the rice grows well. Some registers which are maintained and recorded are ngurit, urit, bunga pucuk bang, and nasi kojongan.

\subsection{Ritual of Nandur 'planting the rice'}

Nandur is an activity of planting the rice. It is derived from tandur 'plant', while nandur means 'to plant'. In this ritual, rice porridge on a special leave called suyuk should be used as an offer; panyugjug consists of daun dapdap putih, andong merah, kayu puring, kayu sisih hijau, kayu temen brumbun. The registers that are maintained in this ritual are nandur, suyuk, kayu temen, kayu andong, kayu sisih, kayu puring.

\subsection{Ritual of Pantun mayusa 105 dina 'the 105-day-old rice'.}

This ritual is called Ngiseh or Mabyakukung 'two-month-old rice'. Byakukung is derived from bya 'dangerous' and kukung 'a shape that shows a part of its body which is protruding' (old Javanese language) 'the shape is like the stomach of a pregnant woman'. It aims to ask the God's blessing for His representation as the Sun with his sacred power of light that protects the rice, which is two-month old having the shape like the pregnant woman's stomach, from the pest [21]. Some offerings are dedicated to the Goddess of Sri; so that there will be more rice. In this stage, the rice seed is like a lizard's tail called as tutug sasihan; later it grows into Sang Hyang Kwaspadan. The offerings include rujak 'salad', tubers, young gading coconut; celokontongan offerings include a knife made of bamboo skin, an egg shell, a yarn which can be put together in kronjo or kroso. Some registers which are rarely found in daily communication include pantun, byukukung, tutug sasihan, Sang Hyang Kawaspadan, celokontongan, kronjo, kroso, tuuh, dina.

\subsection{Ritual of Mluspusin 'the rice plant that starts having the seed'}

This ritual is performed when the rice starts having its seed known as padi wawu mawoh. Mluspus (transitive) means that the rice starts growing its seeds. In some places, this ritual is called mabahin. Mabahin is derived from kebah 'growing bigger'. In the morphological process of mabahin, mabahin means that the seeds grow bigger and more. The ritual is performed when the seeds spread in all parts of the rice. It is conducted near pengalapan. The offerings in the ritual are ketipat sirikan meraka genep, maulam ayam panggang and tubers. Kober gana is installed and the offering is dedicated to the God of Shiva and the Goddess of Uma, so the rice having the full seeds grows well. In addition, nanceb Sunari is installed as a symbol of the Goddess of Vasundhara (Goddess of Fertility). Some registers which are used in this ritual are mluspus, kebah, mawoh, pengalapan, kobergana, nanceb, Sunari.

\subsection{Ritual of Ngadegang Dewa Nini 'creating (making) the Goddess of Nini'}

This ritual is an activity before harvesting. Two symbols are used in the ritual; a symbol of human made of rice plant is called Sanghyang Kaki Manuh and another one is called Nini 
Manuh. These represent thankfulness to the Goddess of Sri as the Goddess of Rice. Kaki Manuh is the symbol of man that is shaped (adegan) as many as 108 badih and the symbol of woman is shaped as many as 54 badih. After kaki manuh is tied and dressed like a man or a woman, the Goddess of Nini is placed in sanggah pengalapan [21]. The offerings needed in the ritual are sanggah and penjor consisting of palagantung given to the Gods in Pura Besakih (Besakih temple). The Goddess of Nini is later placed in the rice field until the harvesting season comes.

\subsection{Ritual of Ngampung /Manyi 'harvesting'}

Ritual of ngampung is performed before the rice is harvested. In some places, the activity of ngampung is called nyangket from the word, sangket, which undergoes a nasalization; sangket changes into nyangket meaning 'hooking' or 'cutting'. In some parts of Bali, this harvesting activity is called manyi. In the ritual, the offerings like yellow rice are put on a place known as tulung (a special place like a basket made of bamboo which is used to place an offering for the God or Goddess); the yellow rice is put in 7 tulung; along with the yellow rice, maulam sarin taluh and plawa sekar kuning are served as the offering. From all of the rituals, some Balinese registers that need to be maintained for its use are:]

Table 1. Registers in the farming rituals

\begin{tabular}{cccc}
\hline No. & Registers in the Farming Rituals & No. & Registers in the Farming Rituals \\
\hline 1 & Ngendagin & 17 & Pantun \\
2 & Pengalapan & 18 & Byakukung \\
3 & Geti-geti & 19 & Tutug sasihan \\
4 & Bunga sulasih & 20 & celokontongan \\
5 & Mapag toya & 21 & kronjo \\
6 & Ngurit & 22 & kroso \\
7 & Pucuk bang & 22 & mluspus \\
8 & Kojongan & 23 & mabahin \\
9 & Nandur & 24 & kober \\
10 & Suyuk & 25 & sunari \\
11 & Kayu temen & 26 & badih \\
12 & Kayu andong & 27 & ngampung \\
13 & Kayu sisih & 28 & manyi \\
14 & Kayu puring & 29 & Penolakmrana \\
15 & Dewa Nini & 30 & mawoh \\
16 & Kakul & 31 & Kebah \\
\hline
\end{tabular}

\section{Conclusion}

Regarding the language maintenance, the farming ritual traditions can be used as media to maintain the use of Balinese registers that are rarely used on the daily basis. Those registers contribute to the Balinese vocabulary. When the rituals are no longer performed due to the modernization, the Balinese registers may be extinct. Those registers are only written or found in such cultural or religious documents. Therefore, the revitalization meaning 'reviving the farming rituals' needs to be undertaken through awig-awig subak, so that the language and the culture remain everlasting. One problem that may emerge is who will revitalize the traditions. From the perspective of traditional wisdom, an institution that is able to manage the local 
wisdom is subak organization which basically functions to manage the activities of farming culture both in the wet field and the dry field.

\section{References}

[1] Q. Lan, "Does Ritual Exist? Defining and Classifying Ritual Based on Belief Theory," $J$. Chinese Sociol., vol. 5, no. 5, pp. 1-14, 2019.

[2] P. I. Nindatu and E. Al., "Pemaknaan Ritual Budi Daya Padi Ladang Suku Sahu Jio Tala'i Padusua,” J. Penelit. Komun. dan Pembang., vol. 19, no. 2, pp. 85-100, 2018.

[3] Y. D. Manafe, "Komunikasi Ritual pada Budaya Bertani Atoni Pah Meto di Timor-Nusa Tenggara Timur," J. Komun., vol. 1, no. 3, pp. 287-298, 2011.

[4] E. J. Jossie and M. A. Sudhir, "Mundiyānkalasam: An Eco-cultural Ritual of Ancient Farming Community," Stud. Tribes Tribals, vol. 10, no. 1, pp. 7-12, 2012.

[5] M. Gluckman, "Les Rites de Passage," in Essays on the Ritual of Social Relations, M. Gluckman, Ed. Manchester: Manchester University Press, 1962, pp. 1-52.

[6] D. P. Artajaya, I. N. Sutjipta, and I. D. P. O. Suardi, "Pelaksanaan Ritual Usahatani Padi Sawah pada Subak Kawasan Perkotaan dan Kawasan Perdesaan Kasus: Subak Ayung, Desa Buduk, Kecamatan Mengwi dan Subak Sulangai, Desa Sulangai, Kecamatan Petang, Kabupaten Badung," E-Jurnal Agribisnis dan Agrowisata, vol. 5, no. 4, pp. 790-800, 2016.

[7] Koentjaraningrat, Kebudayaan Mentalitas dan Pembangunan. Jakarta: PT Gramedia Pustaka Prima, 2002.

[8] M. Doutriaux, "Power, Ideology and Ritual: The Practice of Agriculture in the Inca Empire," Kroeber Anthropol. Soc. Pap., pp. 91-108, 2001.

[9] K. Suradisastra, W. K. Sejati, Y. Supriatna, and D. Hidayat, "Institutional Description of the Balinese Subak," J. Litbang Pertan., vol. 21, no. 1, pp. 11-18, 2002.

[10] I. W. A. A. Wiguna and R. P. Lorenzen, "Past, Present and Future - Perspectives of Balinese Rice Farming," in International Rice Conference 2005, 2005, pp. 1-11.

[11] A. Duranti, Linguistic Anthropology. Cambridge: Cambridge University Press, 1997.

[12] K. Saddhono, "Cultural and social change of foreign students in Indonesia: The influence of Javanese Culture in Teaching Indonesian to Speakers of Other Languages (TISOL)," in IOP Conference Series: Earth and Environmental Science, 2018, vol. 126, no. 1, p. 12091.

[13] N. B. Atmaja, "Kearifan Lokal: Mendekatkan Kesenjangan Antara Teks Ideal dan Teks Sosial Melalui Pikiran Menyintesis dan Multiperspektif," in Seminar Nasional Terkait Jubilium Emas (50 th), 2008.

[14] Nurhadi, Mitologi. Yogyakarta: Kreasi Wacana.

[15] B. H. Hoed, Semiotik dan Dinamika Sosial Budaya. Jakarta: Fakultas Ilmu Pengetahuan Budaya, Universitas Indonesia, 2008.

[16] D. Haryanti and A. B. Wahyudi, "Ungkapan Etnis Petani Jawa di Desa Japanan, Kecamatan Cawas, Kabupaten Klaten: Kajian Etnolinguistik,” Kaji. Linguist. dan Sastra, vol. 19, no. 1, pp. 35-50, 2007.

[17] T. Wahyuni, "Makna Kultural pada Istilah Bidang Pertanian Padi di Desa Boja, Kabupaten Kendal, Jawa Tengah (Sebuah Tinjauan Etnolinguistik)," Jalabahasa, vol. 13, no. 1, pp. 20-30, 2017.

[18] M. Z. Afandi, N. L. Arjani, and I. K. Kaler, "Ritual Neduhin Dalam Sistem Pertanian Masyarakat Desa Bunutin, Kecamatan Kintamani, Kabupaten Bangli, Bali,” J. Humanis, vol. 21, no. 1, pp. 37-45, 2017.

[19] W. Foley, Anthropological Linguistics: An Introduction. Oxford: Blackwell Publishing, 1997.

[20] I. W. Pastika, "Nuansa Gender dalam Bahasa Kita," Srikandi J. Stud. Jender, vol. 2, no. 2, 2002.

[21] S. Bandana and E. Al., "Wacana Ritual Pertanian Sebagai Usaha Pelestarian Bahasa dan Budaya Bali: Sebuah Kajian Linguistik Etnologi,” Denpasar, 2010. 